\title{
EPISTles to Apostles
}

\author{
RODERICK A. MACDONALD*
}

\section{TABLE OF CONTENTS}

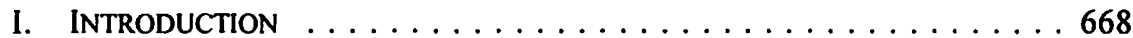

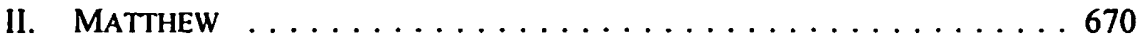

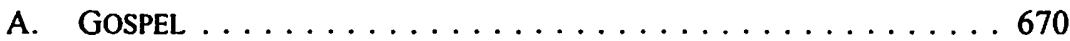

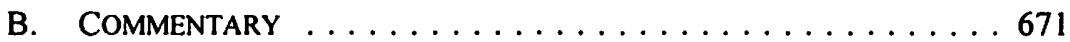

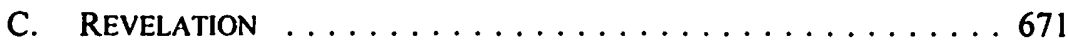

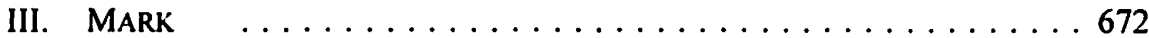

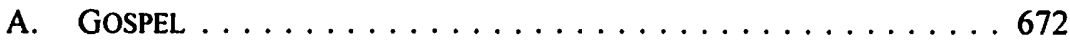

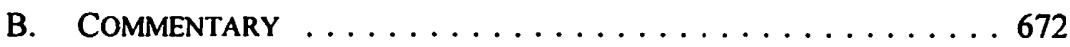

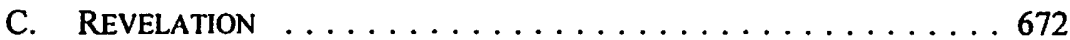

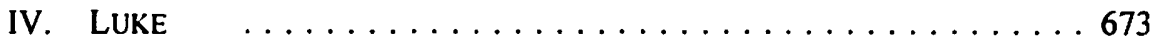

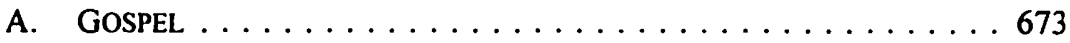

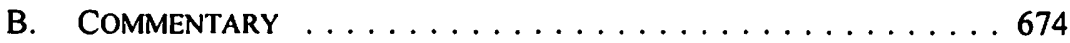

C. REvelation ....................674

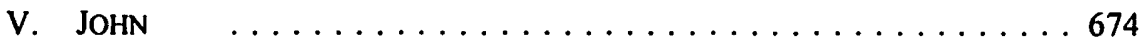

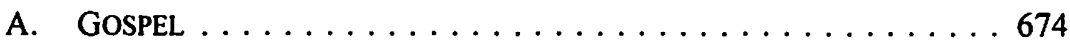

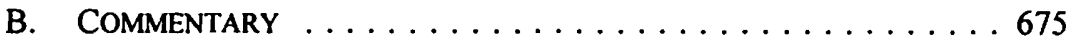

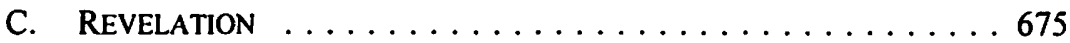

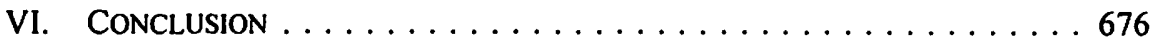

\section{INTRODUCTION}

Northrop Frye was famously known for his claim, in The Great Code,' that the Christian Bible is the key point of reference for the Western European literary canon. $\mathrm{He}$ did not, of course, intend the idea of this literary canon to be understood narrowly. All manner of writing - with the possible exception of recipe books and instructions for assembling bicycles - is, in some measure, to be comprised. More than this, all manner of communication through and by language - be it written or oral, be it read, said, sung or chanted - forms part of this canon. Indeed, all manner of human symbolic expression - whether adjunct to language as in the case of opera, musicals, songs, chants, and circuses or standing apart from language as in the case of painting, sculpture, ballet,

F.R. Scott Professor of Constitutional and Public Law, McGill University; formerly President, Law Commission of Canada. This is a slightly expanded and footnoted version of a paper on the theme of "the interface of the law review and law reform" presented to the session "The Role and Future of the Law Review" at the Annual Meeting of the Canadian Association of Law Teachers, 28 May 2000. Edmonton. Alberta. I should like to thank my colleagues at the Law Commission of Canada, Bruno Bonneville and Susan Zimmerman, for their comments on an earlier version of this paper. I am also grateful to my McGill colleagues Jean-François Gaudreault-Desbiens, Richard Janda, Nicholas Kasirer, and Stephen Toope for discussions about several of the themes raised here. Responsibility for the interpretations suggested is, of course, mine alone.

I See N. Frye, The Great Code : The Bible and Literature (Toronto: Harcourt Brace, 1983). 
dance, and symphonies - is meant to find its intellectual and spiritual roots in biblical myth and allegory.

On this analysis of Frye's claim, legal artifacts are also canonical literary forms. International treaties, constitutions, codes, statutes, regulations, judicial decisions, and administrative determinations are all tributary to the "Great Code." So too are law review articles and law reform commission reports. My aim in this short paper is to appropriate Frye's insight in order to explore what, in the words of the organizers of this session, "the interface of the law review and law reform" might conceivably be. ${ }^{2}$

I do so by organizing my comments around one of the most successful propaganda exercises found in Western literature; namely, the four Gospels of Matthew, Mark, Luke, and John. ${ }^{3} \mathbf{I}$ intend nothing special by my choice of these Gospels as a literary figure from the Christian Bible. I could equally have selected the Revelations of St. John or the various epistles of Paul to the Corinthians, Romans, Galatians, Ephesians, Philippians, Colossians, and Thessalonians. Or I could have used the books of the Pentateuch, the Psalms, the Proverbs or even the Song of Solomon. In other words, for present purposes, the specific textual references are less important than the acknowledgement that biblical allegories can be read as grounding Western thought and action.

Let me be clear that my point is not to proselytize for any particular religious tradition or any particular theological interpretation of the Bible. More generally, my aim is not to make any claims about a religious belief system at all. Rather it is to show that the themes now open for discussion resonate with the deepest concerns of a socio-cultural tradition. So that I may speak authentically, I have chosen my own. This choice is not meant to preempt other choices. I leave it to the reader to find the appropriate analogues in his or her own socio-cultural tradition, a task that it is, obviously, not necessary for me to perform.

There is a further point that should be made by way of introduction. Implicit in this paper is a belief that allegory is a foundational feature of intersubjective communication. Allegory need not always be religious; nor need its cultural referents even be spiritual. In selecting the four Gospels I am, admittedly, committing myself to a structural organization that draws out four themes. But having accepted the number four as a basis of allegory, I might equally have spoken of other quartets: the four seasons of the year; or the four horsemen of the apocalypse; or the four essences in pre-Socratic philosophy - wet, dry,

2 I have previously addressed some of these themes, as concerns law reviews, in "Why Bother With Theory?" in M. Pilkington et al., eds., The Administration of Justice in Commercial Disputes (Montreal: Canadian Institute for the Administration of Justice, 1999) 101; "Le rôle de la doctrine" (1985) C. de D. 1071; “Understanding Civil Law Scholarship in Quebec" (1985) 23 Osgoode Hall L.J. 573. As concerns law reform agencies I have considered these themes in "La réforme du droit et ses organismes" in Actes de la XIVe Conférence des juristes de l'Élat (Cowansville: Yvon Blais, 2000) 377; "Law Reform and Its Agencies" (2000) 79 Can. Bar Rev. 99; "ReCommissioning Law Reform" (1997) 35 Alta. L. Rev. 831.

3 In developing the substantive themes of this paper, I have made extensive use of R. Brown et al., The New Biblical Commentary (London: G. Chapman, 1995) c. 41, 42, 43, 61. I have also drawn from W.J. McDonald, ed., New Catholic Encyclopedia (New York: McGraw-Hill Book, 1967) under R.E. Brown. “Johannine Writings": W.G. Thompson, "Matthew. Gospel According to": D.J. Harrington, “Mark, Gospel According to"; W. Kurz, "Luke-Acts." 
cold, hot; or the four movements in the classical symphony; or the four temptations of Christ; or the "Fab Four" John, Paul, George, Ringo; or the four suits in a deck of playing cards; or the four states of Buddhism - interest, desire, duty, liberation; or even the four points of the compass or the four winds. ${ }^{4}$

While all of these figurative referents could be made to serve my purposes, they would do so in slightly different ways. Like the four Gospels, some obviously have theological overtones. Others, at first blush, do not - although it takes very little reflection on the allegorical possibilities of the four seasons, the four movements of a symphony, and the four points of the compasses or the four winds to see their invitation to transcendence. Still others appear as purely conjectural. Yet again, in the representation of spades, hearts, diamonds, and clubs and the pop-cultural modelling of the roles played by each of the four Beatles, similar themes are evident. So while I eschew sectarian ambitions, I do believe, with Frye, that there is much value in interrogating both law reviews and law reform commissions (seen in their guise of Western European cultural artifacts) with a biblical allegory.

In this instance, I invoke the diverse perspectives adopted in the four accounts of Jesus presented in the four Gospcls. ${ }^{5}$ But I do so in the patterns and forms of literary incantation. In the repetition of structure - of gospel, commentary and revelation - and the fourfold calling up of question and response, my aim is to invite reflection upon the forms, the content, and the purposes of legal scholarship as these are manifest in law reviews and law reform commission documents."

\section{MatThew}

\section{A. GOSPEL}

Conventionally the Gospel of Matthew is seen as a work of mature synthesis, embracing the basic narrative of Mark into which are inserted the $Q$ sayings. The Gospel is meant both as a narrative history and as a doctrinal handbook for Church leaders. The recitation of Jesus' five great discourses (the Sermon on the Mount,' the Missionary

+ Once again, a caveat is in order. In choosing the number four as the organizing motif of my comments, I do not mean to exclude the value of also choosing three or five. Indeed, in some cultural traditions these are easier numbers to work with. One thinks of the Holy Trinity in Christianity and the Buddhist triptych. Indeed, this text would be that much richer were I to repeat the present

3 References are the Bible, Authorized (King James) Version. translated out of the original tongues, and with former translations diligently compared and revised, by his Majesty's special command, A.D. 1611.

1. In this paper I am reading biblical allegory into litcrary form. By doing so. of course, I do not mean to deny that the reverse is possible. For an illustration of how the analytical reflection can move in the other direction see P. Gabel et al., The Bible as Literature, 3d ed. (Toronto: Oxford University
Press, 1999).

( Matthew 5:1-7; 29. 
Discourse ${ }^{8}$ the Parable Discourse, ${ }^{9}$ the Communitary and Discipleship Discourse, ${ }^{10}$ and the Apocalyptic Judgment Discourse ${ }^{11}$ ) is meant to give the pedagogical motif of the Gospel reference to a living person.

Theologically, the Gospel focuses on Jesus, the Son of God, and the near approach of the Kingdom of God. Matthew is at once the most doctrinal of the four Gospels, and it is the only one that actually refers to the Church as an institution. It manifests a particular concern for justice and law through its rejection of the Pharisaic development of the Torah and the Ten Commandments in favour of Jesus' subsumption of the law and the prophets into the love of God and neighbours - what he calls the two great Commandments. ${ }^{12}$

\title{
B. COMMENTARY
}

Law, of course, comprises much more than texts setting out rules of duty and entitlement. Law is a narrative of belief and aspiration.

Two consequences for our symbolization of law flow from the Matthean construction of Jesus' life as pedagogy. First, we would need to see law as a never completed human endeavour, whose achievement is always contingent and subject to revision in the light of greater understanding. Text may be canonical; meaning is not. Second, we would need to see the form of legal texts as imbricated with their purposes. Law's lessons may be given by parable, allegory, metaphor or numerous other literary devices.

\section{REVELATion}

What might be the Matthean meaning for law reviews and law reform commissions and for "the interface of the law review and law reform"? Simply this. The deployment of the printed word should never be directed to an exposition of what is simply presumed to be. Law never just is. Commentary must attend to text, but must go beyond it.

Both law reviews and law reform commissions should seek out and publish material that, like the great Discourses of Matthew, points to justice, ${ }^{13}$ righteousness, ${ }^{14}$ and peace. ${ }^{15}$ Given the vast range of cultural resources of the late twentieth century, this material should embrace poems, plays, lyrics, and chants; and more than this, it should include pictograms, diagrams, tables, charts, and formulae that confront us with the limits of discursive language in symbolizing justice.

In the end, Matthew can be read, through its discourses on faith and community, as evoking the cultural connectedness of law and as inviting those institutions upon which

\author{
Matthew 10:1-42. \\ Matthew 13:1-52. \\ Matthew 18:1-20. \\ Matthew 24:1-25; 46. \\ Matthew 22:36-40. \\ Matthew 7:1-12. \\ Matthew 6:16-34. \\ Matthew 10:5-15.
}


the burden of commentary has traditionally been placed - law reviews and law reform commissions - to reclaim this culture for law.

\section{MARK}

\section{A. GOSPEL}

Mark, the first of the Gospels to be composed, is usually understood as a transcription of the teachings of Peter. Mark was the first to arrange the life and ministry of Jesus parables, sayings, miracles - in a compact geographical-theological structure. Yet, the text of Mark emphasizes what Jesus did, rather than what he said. The Gospel is meant to show that the life of Jesus was itself the supreme parable - from acceptance in Galilee through rejection in Jerusalem; from faithful discipleship of the twelve Apostles to the betrayal by Judas and the denial of Peter. ${ }^{16}$

The centrepiece of Mark's theology is the kingdom of God. Stories of Jesus' life and being and teachings about the meaning of discipleship are used to deepen understanding of the coming kingdom and to prepare the faithful for it. The Gospel reports Jesus' frequent disclaimer of his messianic character, a character that is only revealed in the passion of the crucifixion and resurrection. In Marcan theology the appropriate response to Jesus is discipleship. The Gospel begins by praising the disciples as being at one with Jesus, but as the narrative proceeds they repeatedly fall into misunderstanding. ${ }^{17}$ Whoever wishes to understand the kingdom of God must look only to Jesus - the teacher, the healer, and the crucified.

\section{B. COMMENTARY}

Social ordering through law is not a top-down projection of authority, but rather it is a constant process of interaction between citizens and officials. Both have a socio-political role that invites and obliges them to make, interpret, and apply law.

Two consequences for our symbolization of law flow from the Marcan construction. First, meaning derives from how people give expression to ideals in their interaction in practices, usages, understandings, and fundamental principles and assumptions that necessarily have no textual support. Second, the practices of officials and citizens mutually construct law; the patterns of acceptance and rejection of law's hypotheses are what gives it purchase in peoples' lives.

\section{REVELATION}

What might be the Marcan meaning for law reviews and law reform commissions and for "the interface of the law review and law reform"? Here is a hypothesis. The normative

On Judas' betrayal of Jesus, see Mark 14:10-11; 43-45; on Peter's renunciation of Jesus, see Mark 14:66-72.

17 disciples' misunderstanding, see generally Mark 8:1-10; 52. 
weight of officially announced law comes as much from the rituals associated with Parliamentary practice, police and law office procedures, and courtroom processes as it does from the actual texts of statutes, regulations, judgments, and contracts.

Both law reviews and law reform commissions cannot be the repository of nineteenthcentury static, text-based knowledge. Their message must be carried by interactive vehicles like web sites, and other iterative forms. No longer will it be possible for legal commentary to be canonical, just as no longer will it be possible to state a sharp distinction between word and deed.

In the end, Mark can be read, through its focus on discipleship, as evoking the need for legal texts to express symbolic as well as instrumental meaning and as inviting those institutions which generate texts meant to guide action - law reviews and law reform commissions - to resist publishing mere catechism.

\section{LUKE}

\section{A. GOSPEL}

Luke is the most Hellenic and pluralistic of the Gospels, adapting Greek literary forms to its purpose: parallelism, literary promise and fulfilment. Like Matthew, Luke uses both Mark and $Q$ as sources and presents Jesus as the promised saviour of both Israel, and of all people. The Gospel moves in the early Pauline tradition, showing a special interest for outcasts and the oppressed - especially the poor and the disabled - and emphasizing the role of women in the ministry. Many of the best known parables - the Good Samaritan, ${ }^{18}$ the Prodigal Son, ${ }^{19}$ and the Rich Man and Lazarus ${ }^{20}$ - are found only in Luke.

Theologically, Luke is carried forward in the Acts of the Apostles through the theme of the rejected prophet and the possibility of mercy flowing from repentance. The aim is to show that the reconstituted Israel, after the destruction of the Temple, is open to all those of the "chosen people" who would repent their initial rejection of Jesus and all those Gentiles who would believe in him. Luke is at pains to point out that social status, ethnic heritage, and religious self-justification neither guarantee membership among the elect, nor exclude; the lame, the blind, the poor, and women are also admissible. ${ }^{21}$ Jesus' mission is an inclusive one as he seeks out sinners and restores them to union with God. 


\section{B. COMMENTARY}

On one account, law is about power and coercion; on another account, it is about liberation and freedom. Both are always present, whether in respect of official unitary law of the state or in respect of the implicit pluralistic law of everyday life.

Two consequences for our symbolization of law flow from the Lucan construction of error and repentance. First, neither the critical left, that sees only the oppression of law's violence, nor the libertarian right, that sees only a role for law to the extent it enhances market freedom, has a monopoly on truth. Society is a reflection of relationships relationships we seek out and build throughout our lives. Second, at the foundation of social life is a measure of predictability in personal and social interactions. Being able to recognize and find meaning in the actions of others, and being confident that our own actions will be recognized and understood more or less as we intend them allows us to dream, to make plans, and to act in relative security.

\section{Revelation}

What might be the Lucan meaning for law reviews and law reform commissions and for "the interface of the law review and law reform"? A key element of law is to acknowledge and overcome disparities in social power and to engage the excluded in the discourse of law. The outcasts must be given the language of law just as the law must embrace the language of outcasts.

Both law reviews and law reform commissions must find ways to reach out to those whose primary symbolic extroversions are elsewhere. The morality plays of the World Wrestling Federation, the video language of much pop music, Harlequin romances, Louis Lamour's western pulp fiction, comic books, National Film Board animated shorts, and Internet hyperlinks are languages that speak out against disempowerment.

In the end, Luke can be read, through its parables of the oppressed, as evoking the need to create arenas for struggle and contestation and as inviting those institutions that have assumed the burden of social engagement - law reviews and law reform commissions - to reclaim the plurality of law.

\section{JOHN}

\section{A. GoSPEL}

John, the last of the Gospels to be written, is the only Gospel that is not synoptic. It has little temporal narrative and no parables. It is rather a meditation on the identity of Jesus and an affirmation of creed. The synoptic Gospels make the revelation of Jesus as Messiah through their resurrection climax; whereas John is an expression of Johannine faith that acknowledges the Christ identity from its outset. In John, Jesus speaks in symbolic discourses, punctuated by the narrator's asides. This alternation reflects the dual nature of Jesus as being the Son of Man and the Son of God. 
Johannine theology focuses on miracles and on the "I am" sayings that express Jesus' meanings in a series of striking metaphors. The literary dynamics of the Gospel - its use of symbolism and equivocation - mark the text as intended for the Johannine community. The ambition is Christological; it is meant to explain the nature of Jesus. John is foundationally the source of the doctrine of the trinity by its emphasis on the preexistent Word. Its parallelism between acceptanceand rejection, and between descent from God and resurrection, is a reminder of the ambivalence and transience of all things human.

\section{B. COMMENTARY}

Law is a human aspiration that offers the concepts, the procedures, and the vocabulary by and through which we discover, describe, modulate, and nurture our place in the family, in the community, in institutions, and in society. A failure to ask what we expect of our law is a failure to ask what we expect of ourselves.

Two consequences for our symbolization of law flow from the Johannine construction of Jesus' identity. First, overuse of its particular form is a symptom of law's malaise. Whenever we see a problem, we say "there ought to be a rule." Because our societal diagnostic skills are often inadequate when confronted with equivocation, we do not ask why and how a perceived problem has been framed and could be reframed. Second, the capacity of law to educate and incite reflection about diverse human identities is not well understood. We have made narrowly cast rights and obligations of disembodied "legal subjects" into the definition of our entitlements, our duties, and our expectations.

\section{Revelation}

What might be the Johannine meaning for law reviews and law reform commissions and for "the interface of the law review and law reform"? The messages of law are wrapped in ambivalence and contingency. They are meditations on identity and aspiration.

Both law reviews and law reform commissions must decline to publish hagiographies of judges and summaries of recent legal history. Most legal writing does not speak normatively to social action because it presumes that law can be textual without at the same time being "the way, the truth and the life."22

In the end, John can be read, through the metaphoric affirmations "I am ...," as evoking the need to recognize the fundamental plurality of personal identity and as inviting those institutions that have assumed the burden of interpretation and understanding - law reviews and law reform commissions - to acknowledge that "[i]n the beginning was the Word." 23 


\section{Conclusion}

In concluding this brief exploration of "the interface of the law review and law reform" I should like to reinterpret its four themes.

First, I want to emphasize a point about the nature of writing in law review articles and law reform commission reports. All texts are mirrors. All texts are culturally-grounded symbols. They mean more than they say. Let us not become fixated upon the form and style of legal texts. Law reform is about changing how we write about law. Suppose that instead of the formulaic recipe-book model of judgment-writing that now seems to be adopted in the Supreme Court, judgments came to be written in the form of a sonnet or a villanelle. Suppose, further, that the court were to write in iambic pentameter, or anapests, or trochées, or spondées, or dactyls. Would factums and law review articles follow suit?

If a law review is to intersect with the preoccupations of law reform, it must directly confront questions like: how would it matter if we were to think and write anapestically: "May it please, each of you - I should think, with respect - that this case, now at bar, has been settled, and is moot," rather than iambically: "My Lords, I think, this case, is moot"?

Second, law reform is fundamentally about changing the way law structures understanding and action. It is hardly the task of a law review and an independent law reform agency merely to repeat standard explanations of human phenomena. The task is to reframe issues. Slavery ends not by rearguing the categories of human beings who may be enslaved - the recognition of its evil begins with recategorizing slaves not as property, but as persons. Contractual exploitation ends not by inventing doctrines of unconscionability - the recognition of its injustice begins with rethinking what voluntarism (or free will) in this world actually entails.

So if a law review is to intersect with the preoccupations of law reform, it must explicitly renounce being "useful" in the instrumental sense, to both lawyers and judges. Rather, it is by not being useful - by engaging lawyers and judges in a dialogue of justification with authors and commentators about the socio-political position they all hold in the legal universe - that the two contribute most to law's pedagogy.

Third, we have to recognize the role of law in obscuring or suppressing the diversity of human experience. Law reform is about changing the voice of law from catechism to heresy. Interpretation and understanding are plural and open to argument. But since law is too often about power and coercion, certain interpretations and certain understandings come to predominate. We should not imagine that law reviews and law reform commissions are exempt from hiding power and coercion behind the language of authoritative interpretation.

So if a law review is to intersect with the preoccupations of law reform, it must consciously seek to discover who is disadvantaged, the nature of the disadvantage, and the incomplete capacity of our words to state and to overcome that disadvantage. 
Fourth, each time we speak or write, we are telling a story. And since our words are strung out one after the other, necessarily we make choices about what features of the story being told are important, in what order they should be presented, and how they should be emphasized. All stories are both equivocal and contingent. Since we are not able to say everything all at once - if at all - the manner of our telling a story is as important as its content.

Again, since we are not able to say everything all at once, every statement we make will necessarily be a partial truth. The meaning of the courtroom injunction to "tell the truth, the whole truth, and nothing but the truth" reposes in its admission that the most damnable lies are not overt falsehoods. Overt falsehoods can be recognized and contested. Most insidious is partial truth masking its partiality.

We should never forget that law review articles and law reform commission reports are stories too. They do not, and cannot, tell the whole truth; at the same time, they can, and do, tell the truth. Only part of any story is recounted by a text. We consciously negotiate how we shall tell our partial truths to each other in order to tell a greater truth to the world. Because truth can never be pinned down once and for all, finding the allegories that let us share our partial truths is as important as the attempt to agree on our transcendent truths. Truth must be constantly reinterpreted and reunderstood, lest its partiality become fixed in a lie. There is no easy route to agreement about either our partial prophesies (whether offered up by law reviews or law reform commissions) or about the perfect truths unattainable in this world. 